\title{
溶存酸素濃度の過飽和状態が 養液栽培トマトの生育および養分吸収におよぼす影響
}

\author{
田中剛毅・山下洋平・中林和重 \\ 明治大学農学部 214-8571 神奈川県川崎市多摩区東三田 1-1-1
}

\begin{abstract}
Effect of Supersaturation of Dissolved Oxygen on the Growth of Tomato Plants and Nutrient Uptake in Hydroponic Culture
\end{abstract}

\author{
Gouki TANaKa, Youhei Yamashita and Kazushige NAKABAYASHI \\ Department of Agricultural Chemistry, Faculty of Agriculture, Meiji University, \\ 1-1-1 Higashimita, Tama, Kawasaki 214-8571, Japan
}

\begin{abstract}
The concentration of dissolved oxygen in a culture solution is one of the most important environmental factors affecting the growth of the tops and roots of plants under hydroponic culture. In particular, the roots of tomatos readily absorb oxygen in the solution, and are thus sensitive to the concentration of dissolved oxygen. Thus, the effects of dissolved oxygen concentration on the morphology and growth of roots, water uptake rate and nutrient uptake were investigated. In hydroponic culture, the supply of dissolved oxygen is essential. Previously, we reported that supersaturation of dissolved oxygen in culture solution promoted the uptake of phosphate. In the present study, we found that supersaturation of dissolved oxygen in culture solution low in nitrogen and phosphate led to an increase in plant height, fresh weight of stems and leaves and root weight. It also increased the phosphorus concentration in the sap, stems, leaves and fruits of tomato plants.
\end{abstract}

Keywords: dissolved oxygen,phosphorus concentration,hydroponic culture,tomato plants

\section{緒 言}

養液栽培において培養液中の溶存酸素濃度は植物の地 上部および地下部の生育にとって重要な環境要因の 1 つ である11。特にトマトの根は, 培養液中の酸素要求性が 高い性質があり ${ }^{2)}$, 溶存酸素濃度に比較的敏感である. したがって，養液栽培では溶存酸素の効率的な供給が必 要不可欠である．今までに溶存酸素濃度の高低と植物の 根の形態や生育 ${ }^{3,4,5)}$, 吸水速度6), 養分吸収 ${ }^{7)}$ に関する研 究がされている.我が研究室でも, 培養液中の溶存酸素 濃度の過飽和状態が，トマトの地下部におよほす影響に

2000 年 6 月 27 日受付

2000 年 11 月 10 日受理
ついて研究しており ${ }^{8)}$ ，それに伴った地上部への影響を 課題としてきた. 本報告では培養液中の溶存酸素濃度の 過飽和状態が, 養液栽培トマトの生育, 養分吸収および 果実の収量におよぼす影響について検討したので報告す る.

\section{材料および方法}

\section{1. 試験方法}

\section{(1) 試験区}

4 要因 2 水準の直交表による実験計画法 ${ }^{9)}$ で行った (Table 1). 即ち, 培養液への酸素添加の有無について 2 水準, 培養液の窒素濃度について標準濃度と低濃度の 2 水準, 培養液のリン濃度について標準濃度と低濃度の 
Table 1 Orthogonal table

\begin{tabular}{|c|c|c|c|}
\hline $\mathrm{O}_{2}$ gas & Nitrate concentration & Phosphate concentration & Heater \\
\hline \multirow{8}{*}{ supplemented } & \multirow{4}{*}{ standard } & \multirow{2}{*}{ standard } & $\mathrm{E}$ \\
\hline & & & $\mathrm{NE}$ \\
\hline & & \multirow{2}{*}{ low } & $\mathrm{E}$ \\
\hline & & & $\mathrm{NE}$ \\
\hline & \multirow{4}{*}{ low } & \multirow{2}{*}{ standard } & $\mathrm{E}$ \\
\hline & & & $\mathrm{NE}$ \\
\hline & & \multirow{2}{*}{ low } & $\mathrm{E}$ \\
\hline & & & $\mathrm{NE}$ \\
\hline \multirow{8}{*}{ not supplemented } & \multirow{4}{*}{ standard } & \multirow{2}{*}{ standard } & $\mathrm{E}$ \\
\hline & & & $\mathrm{NE}$ \\
\hline & & \multirow{2}{*}{ low } & $\mathrm{E}$ \\
\hline & & & $\mathrm{NE}$ \\
\hline & \multirow{4}{*}{ low } & \multirow{2}{*}{ standard } & $\mathrm{E}$ \\
\hline & & & $\mathrm{NE}$ \\
\hline & & \multirow{2}{*}{ low } & $\mathrm{E}$ \\
\hline & & & $\mathrm{NE}$ \\
\hline
\end{tabular}

E; equipped, NE; not equipped

Table 2 Nitrate and phosphate concentrations (me/L)

\begin{tabular}{ccc}
\hline \hline Fertilizer & Standard & Low \\
\hline Nitrate & & \\
\hline $\mathrm{Ca}\left(\mathrm{NO}_{3}\right)_{2} \bullet 4 \mathrm{H}_{2} \mathrm{O}$ & 5 & 2 \\
$\mathrm{KNO}_{3}$ & 2.5 & 1 \\
\hline total & 7.5 & 3 \\
\hline Phosphate & & \\
\hline $\mathrm{KH}_{2} \mathrm{PO}_{4}$ & 1.5 & 0.6 \\
\hline
\end{tabular}

2 水準, 加温装置使用の有無について 2 水準を設け，こ れらの要因の組み合わせにより 16 種の試験区を設定し た．施肥設計は Carol Reiss ${ }^{10)}$ の処方に基づいて行った (Table 2). 栽培期間中の加温装置使用区の培養液温度

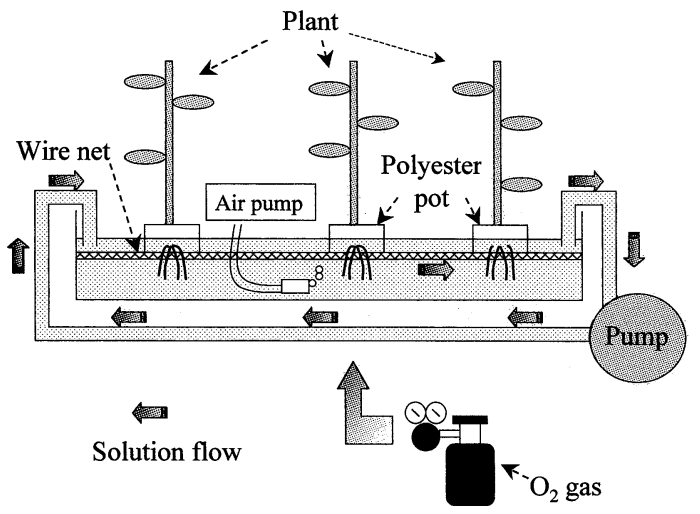

Fig. $1 \mathrm{O}_{2}$ gas added system
は $25^{\circ} \mathrm{C}$ に設定し, 加温装置未使用区の培養液温度は 10 〜 $15^{\circ} \mathrm{C}$ であった. 酸素添加には医療用酸素ボンべ(純度 99\%)を使用し，栽培ベットからポンプで培養液を吸い 上げ $(3.0 \mathrm{~L} / \mathrm{min})$, 栽培ベットに戻す途中で添加した (Fig. 1). 培養液循環の際に行う酸素添加は, 光合成が 行われる間に溶存酸素の過飽和状態が根部に影響を及ほ すことを考慮し $7: 00 \sim 9: 00,11: 00 〜 13: 00,17: 00$ 〜 19:00 と昼間 1 日 3 回行い, 1 回の酸素添加は各試験 区 15 分, 酸素添加量は $0.8 \mathrm{~L} /$ 分とした. なお空気の供 給にはエアーポンプを用い, 酸素添加区では添加時間を 除いて 1 日中, 酸素無添加区では 1 日中行った。

\section{(2) 栽培概要}

栽培は明治大学生田校舎内のガラス温室で行ない, 栽 培期間中の室温は $25 \sim 30^{\circ} \mathrm{C}$ に管理した。供試作物には トマト(学名 Lycopersicum esculentum MILL.)のチェリ ゴールド(トキタ種苗株式会社製)を使用した. 1998 年 9 月 8 日にバーミキュライトの播種床に播種し, 子葉が展 開し，本葉が見え始めた 9 月 14 日にポリエステル製ポ ット ( (CLP 7575 C) 東洋紡績株式会社製) に仮植し，10 月 12 日にたん液式水耕栽培の栽培ベット $(90 \mathrm{~cm} \times 36.5$ $\mathrm{cm} \times 25 \mathrm{~cm}$, 標準培養液 $20 \mathrm{~L})$ に 3 株ずつ定植した。窒 素濃度, リン濃度の低濃度水準への変更は 10 月 28 日に 行い, 同時に酸素添加も開始した。摘心は第 7 果房上葉 2 枚を残して随時行い, 摘果は行わなかった。収穫は随 時行い, 栽培は 1999 年 2 月 22 日に終了した。 なお, 栽 培ベット内部の培養液の交換は 3 週間に 1 度の割合で合 
計 6 回行った。

\section{2. 調査および試験方法}

\section{(1) 培養液の溶存酸素濃度}

培養液の溶存酸素濃度測定には溶存酸素計 ( (OM-12) 株式会社堀場製作所製)を用いた。電極は栽培ベット中 央に設置した. なお，電極の設置位置による溶存酸素濃 度の差はみられなかった。

\section{（2）生育および収量調査}

栽培終了時の草丈, 茎葉生重量および根乾重量を調査 した。果実の生収量測定は収穫時に行い，合計を果実総 収量とした。

\section{(3) 吸水量}

栽培期間中の培養液損失量を吸水量とした。なお培養 液損失がおこると培養液は自動的に補充され，栽培ベッ トの液面を常に一定に保つようにした。

\section{（4）汁液分析方法}

汁液分析は 1998 年 12 月 11 日に行った。汁液分析に は第 5 果房直下の葉柄を搾汁後，濾過を行い得られた濾 液を用い, 硝酸態窒素は簡易比色計 ( (RQflex) MERCK 社製)で定量した. カリウム, カルシウム, マグネシウ ムについては原子吸光光度法で, リンは ICP 発光分光 分析法で定量した.

\section{（5）植物体成分分析方法}

葉茎部は通風乾燥機 $\left(70^{\circ} \mathrm{C}, 24 \mathrm{hr}\right)$ で，果実は真空凍 結乾燥機で乾燥した。 その後それぞれの試料をケルダー ル分解し, 全窒素を水蒸気蒸留法 ${ }^{11)}$ で定量した。 カリウ ム, カルシウム, マグネシウムについては原子吸光光度 法で, リンはバナドモリブデン酸による比色法 ${ }^{12)}$ で定量 した.

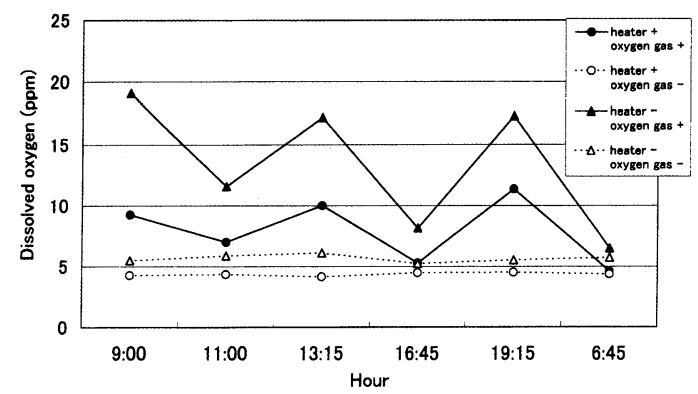

Fig. 2 Dissolved $\mathrm{O}_{2}$ concentration fluctuations within a day

\section{結果および考察}

\section{1. 酸素添加による溶存酸素濃度の変化}

1998 年 12 月 9 10 日の溶存酸素濃度の経時変化を Fig. 2 に示した. 溶存酸素培養液の溶存酸素濃度は加温 装置使用区では酸素添加により増加し, 酸素添加直後に 過飽和状態となった. 加温装置未使用区では酸素添加に より日中は過飽和状態を保ち続けた。 また加温装置使用 区では, 加温装置未使用区よりも水温が高いため, 溶存 酸素濃度は低くなり ${ }^{1)}$, この溶存酸素濃度の変化は, 栽 培期間中どの日も同様であった。 なお溶存酸素濃度の過 飽和状態とは飽和值 $\left(25^{\circ} \mathrm{C}, 8.4 \mathrm{ppm}\right)^{1)}$ を超えた濃度の ものを定義した。

\section{2. 生育および収量調查}

生育および収量調査結果を Table 3 に示した。

草丈は酸素添加の有無により影響された。即ち, 酸素 無添加区で平均 $151 \mathrm{~cm}$ であったのに対し, 酸素添加区 では平均 $168 \mathrm{~cm}$ と比較的高い傾向があった(分散比 1. 91 , 信頼度 $77 \%$ ).

茎葉生重量は酸素添加の有無により影響された。即ち, 酸素無添加区で平均 $1747 \mathrm{~g}$ であったのに対し, 酸素添 加区では平均 $2003 \mathrm{~g}$ と比較的高い值となる傾向があっ た(分散比 2.32 , 信頼度 $81 \%$ )。

根乾重量は酸素添加の有無に影響され, 酸素無添加区 で平均 $37.4 \mathrm{~g}$ であったのに対し, 酸素添加区では平均 $48.1 \mathrm{~g}$ と高い值であった(分散比 20.81 , 信頼度 $99 \%$ ). また，窒素施肥濃度にも影響された。即ち, 窒素標準濃 度区は $42.0,35.4 \mathrm{~g}$ で平均 $38.7 \mathrm{~g}$ であったのに対し, 窒素低濃度区では $54.1,39.3 \mathrm{~g}$ で平均 $46.7 \mathrm{~g}$ と高い值 であった(分散比 11.44 , 信頼度 $98 \%$ )。ささらに, 加温装 置使用の有無により影響された. 即ち, 加温装置未使用 区は23.2, 34.5 49.6，49.9，28.5,35.2,37.9, 39.6g で平均 $37.3 \mathrm{~g}$ であったのに対し, 加温装置使用区では $52.9,57.5,66.8,50.0,45.9,32.2,46.2,33.5 \mathrm{~g}$ で平 均 $48.1 \mathrm{~g}$ と高い值であった(分散比 21.39 , 信頼度 $99 \%$ ). 果実の収量は, 要因ごとの有意な差がみられず全平均 $1089 \mathrm{~g}$ であった.

吸水量は, 要因ごとの有意な差はみられず全栽培期間

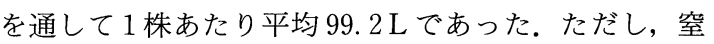
素低濃度区では酸素添加の有無により影響され酸素添加 区の吸水量は増加する傾向があった。

これらの結果から酸素添加による溶存酸素の過飽和状 態が，地上部および地下部の生育を促進させたと考えら れた。また，地下部に関しては，窒素欠乏によるストレ 
Table 3 Effect of supersaturation of dissolved oxygen on growth and water uptake in tomato plants in hydroponic culture

\begin{tabular}{|c|c|c|c|c|c|c|c|c|}
\hline \multirow{3}{*}{$\mathrm{O}_{2}$ gas } & \multirow{3}{*}{$\begin{array}{l}\text { Test items } \\
\begin{array}{l}\text { Nitrate } \\
\text { concentration }\end{array}\end{array}$} & \multirow{3}{*}{$\begin{array}{l}\text { Phosphate } \\
\text { concentration }\end{array}$} & \multirow{3}{*}{ Heater } & \multicolumn{3}{|c|}{ Growth and yield } & & \multirow{3}{*}{$\begin{array}{l}\text { Water uptake } \\
\text { (L) }\end{array}$} \\
\hline & & & & Height & Weight $(g$ & /plant & & \\
\hline & & & & & Stem and leaves & Roots & Fruit & \\
\hline \multirow{14}{*}{ supplemented } & \multirow{6}{*}{ standard } & \multirow{2}{*}{ standard } & $\mathrm{E}$ & 163 & 2378 & 52.9 & 1175 & 120.4 \\
\hline & & & $\mathrm{NE}$ & 119 & 1028 & 23.2 & 1037 & 66.1 \\
\hline & & avg. & & 141 & 1703 & 38.0 & 1106 & 93.3 \\
\hline & & \multirow{2}{*}{ low } & $\mathrm{E}$ & 188 & 2462 & 57.5 & 1614 & 130.3 \\
\hline & & & $\mathrm{NE}$ & 125 & 1346 & 34.5 & 723 & 80.7 \\
\hline & & avg. & & 157 & 1904 & 46.0 & 1169 & 105.5 \\
\hline & avg. & & & 149 & 1804 & 42.0 & 1137 & 99.4 \\
\hline & \multirow{6}{*}{ low } & \multirow{2}{*}{ standard } & $\mathrm{E}$ & 185 & 2560 & 66.8 & 1178 & 140.4 \\
\hline & & & $\mathrm{NE}$ & 215 & 2495 & 49.6 & 1152 & 139.0 \\
\hline & & avg. & & 200 & 2528 & 58.2 & 1165 & 139.7 \\
\hline & & \multirow{2}{*}{ low } & $\mathrm{E}$ & 134 & 1512 & 50.0 & 622 & 89.8 \\
\hline & & & $\mathrm{NE}$ & 213 & 2241 & 49.9 & 1337 & 87.8 \\
\hline & & avg. & & 174 & 1877 & 49.9 & 980 & 88.8 \\
\hline & avg. & & & 187 & 2202 & 54.1 & 1072 & 114.3 \\
\hline avg. & & & & 168 & 2003 & 48.1 & 1105 & 106.8 \\
\hline \multirow{14}{*}{ not supplemented } & \multirow{6}{*}{ standard } & \multirow{2}{*}{ standard } & $\mathrm{E}$ & 190 & 2714 & 45.9 & 1719 & 145.0 \\
\hline & & & $\mathrm{NE}$ & 133 & 1131 & 28.5 & 695 & 54.6 \\
\hline & & avg. & & 162 & 1923 & 37.2 & 1207 & 100.0 \\
\hline & & \multirow{2}{*}{ low } & $\mathrm{E}$ & 134 & 1755 & 32.2 & 857 & 86.0 \\
\hline & & & $\mathrm{NE}$ & 155 & 1778 & 35.2 & 1447 & 88.0 \\
\hline & & avg. & & 145 & 1767 & 33.7 & 1152 & 87.0 \\
\hline & avg. & & & 153 & 1845 & 35.4 & 1180 & 93.4 \\
\hline & \multirow{6}{*}{ low } & \multirow{2}{*}{ standard } & $\mathrm{E}$ & 143 & 1370 & 46.2 & 608 & 87.0 \\
\hline & & & NE & 158 & 1924 & 37.9 & 994 & 87.6 \\
\hline & & avg. & & 151 & 1647 & 42.0 & 801 & 87.3 \\
\hline & & \multirow{2}{*}{ low } & $\mathrm{E}$ & 124 & 1237 & 33.5 & 729 & 84.5 \\
\hline & & & $\mathrm{NE}$ & 172 & 2066 & 39.6 & 1543 & 99.6 \\
\hline & & \multirow[t]{2}{*}{ avg. } & & 148 & 1652 & 36.5 & 1136 & 92.1 \\
\hline & avg. & & & 149 & 1649 & 39.3 & 969 & 89.7 \\
\hline avg. & & & & 151 & 1747 & 37.4 & 1074 & 91.5 \\
\hline
\end{tabular}

ス ${ }^{13)}$ を回避するために発達が促進され, その結果吸水量 も増加したと推察される. 収量については, 試験要因に よる有意な差があらわれなかった。一般的なトマトのハ ウス促成栽培では果実の摘果を行う ${ }^{14,15)}$ が，今回の栽培 では摘果を行わなかった.これは摘果をすることにより 硝酸態窒素, カルシウム, マグネシウムの吸収量が多く

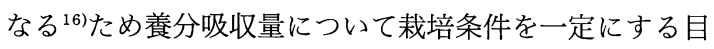
的のためである.

\section{3. 汁液中の無機成分濃度}

汁液中の無機成分濃度を Table 4 に示した.

\section{1）硝酸態窒素}

汁液中の硝酸態窒素濃度は窒素施肥濃度に影響された。 即ち, 窒素低濃度区は $0.068,0.059 \%$ で平均 $0.064 \%$
であったのに対し，窒素標準濃度区では 0.158 , $0.127 \%$ で平均 $0.143 \%$ と高かった(分散比 12.42 , 信頼 度 $98 \%$ ).

\section{2) リ}

汁液中のリン濃度は酸素添加の有無に影響された。即 ち, 酸素無添加区で平均 $0.028 \%$ であったのに対し, 酸素添加区では平均 $0.035 \%$ と高い傾向があった(分散 比 2.37 , 信頼度 $81 \%$ )。 また，リン施肥濃度にも影響さ れた. 即ち,リン低濃度区は $0.034,0.040,0.020$, $0.009 \%$ と平均 $0.026 \%$ であったのに対し，リン標準濃 度区では $0.033,0.035,0.051,0.031 \%$ 平均 $0.038 \%$ と 高い傾向があった(分散比 5.68 , 信頼度 $93 \%$ )。

更に, リン施肥濃度と酸素添加の有無との組み合わせ 
Table 4 Effect of supersaturation of dissolved oxygen on inorganic composition of plant sap

\begin{tabular}{|c|c|c|c|c|c|c|c|c|}
\hline \multicolumn{4}{|c|}{ Test items } & \multicolumn{5}{|c|}{ Content $(\%)$ of plant sap } \\
\hline $\mathrm{O}_{2}$ gas & $\begin{array}{l}\text { Nitrate } \\
\text { concentration }\end{array}$ & $\begin{array}{l}\text { Phosphate } \\
\text { concentration }\end{array}$ & Heater & $\mathrm{N}$ & $\mathrm{P}$ & $\mathrm{K}$ & $\mathrm{Ca}$ & $\mathrm{Mg}$ \\
\hline \multirow{14}{*}{ supplemented } & \multirow{6}{*}{ standard } & \multirow{2}{*}{ standard } & $\mathrm{E}$ & 0.090 & 0.033 & 0.322 & 0.081 & 0.029 \\
\hline & & & $\mathrm{NE}$ & 0.136 & 0.032 & 0.511 & 0.167 & 0.037 \\
\hline & & avg. & & 0.113 & 0.033 & 0.417 & 0.124 & 0.033 \\
\hline & & \multirow{2}{*}{ low } & $\mathrm{E}$ & 0.249 & 0.051 & 0.506 & 0.171 & 0.065 \\
\hline & & & $\mathrm{NE}$ & 0.158 & 0.017 & 0.518 & 0.156 & 0.061 \\
\hline & & \multicolumn{2}{|l|}{ avg. } & 0.203 & 0.034 & 0.512 & 0.163 & 0.063 \\
\hline & avg. & & & 0.158 & 0.033 & 0.464 & 0.144 & 0.048 \\
\hline & \multirow{6}{*}{ low } & \multirow{2}{*}{ standard } & $\mathrm{E}$ & 0.059 & 0.037 & 0.314 & 0.169 & 0.045 \\
\hline & & & $\mathrm{NE}$ & 0.045 & 0.032 & 0.546 & 0.239 & 0.060 \\
\hline & & avg. & & 0.052 & 0.035 & 0.430 & 0.204 & 0.053 \\
\hline & & \multirow{2}{*}{ low } & $\mathrm{E}$ & 0.102 & 0.039 & 0.438 & 0.222 & 0.063 \\
\hline & & & $\mathrm{NE}$ & 0.068 & 0.041 & 0.500 & 0.283 & 0.067 \\
\hline & & \multirow[t]{2}{*}{ avg. } & & 0.085 & 0.040 & 0.469 & 0.252 & 0.065 \\
\hline & avg. & & & 0.068 & 0.037 & 0.450 & 0.228 & 0.059 \\
\hline \multicolumn{2}{|l|}{ avg. } & & & 0.113 & 0.035 & 0.457 & 0.186 & 0.053 \\
\hline \multirow{14}{*}{ not supplemented } & \multirow{6}{*}{ standard } & \multirow{2}{*}{ standard } & $\mathrm{E}$ & 0.158 & 0.063 & 0.451 & 0.168 & 0.052 \\
\hline & & & $\mathrm{NE}$ & 0.102 & 0.039 & 0.366 & 0.159 & 0.031 \\
\hline & & avg. & & 0.130 & 0.051 & 0.409 & 0.164 & 0.041 \\
\hline & & \multirow{2}{*}{ low } & $\mathrm{E}$ & 0.090 & 0.023 & 0.333 & 0.178 & 0.042 \\
\hline & & & $\mathrm{NE}$ & 0.158 & 0.017 & 0.490 & 0.218 & 0.057 \\
\hline & & \multirow[t]{2}{*}{ avg. } & & 0.124 & 0.020 & 0.412 & 0.198 & 0.049 \\
\hline & avg. & & & 0.127 & 0.035 & 0.410 & 0.181 & 0.045 \\
\hline & \multirow{6}{*}{ low } & \multirow{2}{*}{ standard } & $\mathrm{E}$ & 0.058 & 0.039 & 0.455 & 0.195 & 0.047 \\
\hline & & & $\mathrm{NE}$ & 0.021 & 0.024 & 0.474 & 0.171 & 0.043 \\
\hline & & avg. & & 0.040 & 0.031 & 0.465 & 0.183 & 0.045 \\
\hline & & \multirow{2}{*}{ low } & $E$ & N. D.* & 0.007 & 0.366 & 0.108 & 0.022 \\
\hline & & & $\mathrm{NE}$ & 0.079 & 0.011 & 0.583 & 0.227 & 0.059 \\
\hline & & avg. & & 0.079 & 0.009 & 0.475 & 0.168 & 0.040 \\
\hline & \multirow[t]{2}{*}{ avg. } & & & 0.059 & 0.020 & 0.470 & 0.175 & 0.043 \\
\hline avg. & & & & 0.093 & 0.028 & 0.440 & 0.178 & 0.044 \\
\hline
\end{tabular}

E; equipped, NE; not equipped ${ }^{*}$ N. D. $=$ Not Detectable

における汁液中のリン濃度は，リン標準濃度，酸素添加 区では $0.033,0.035 \%$ で平均 $0.034 \%$, リン標準濃度, 酸素無添加区では $0.051,0.031 \%$ で平均 $0.041 \%$, リ ン低濃度, 酸素添加区では $0.034,0.040 \%$ で平均 0. 037\%，リン低濃度，酸素無添加区では 0.020，0.009\% で平均 $0.015 \%$ となり, 溶存酸素の過飽和状態により, リン低濃度区の汁液中リン濃度がリン標準濃度区と同等 の值となった(分散比 9.44 , 信頼度 $97 \%$ ).

\section{3) カリウム}

汁液中のカリウム濃度は加温装置使用の有無に影響さ れた。即ち, 加温装置使用区は $0.322,0.506,0.314$, $0.438,0.451,0.333,0.455,0.366 \%$ と平均 $0.398 \%$ で あったのに対し, 加温装置末使用区では $0.511,0.518$, $0.546,0.500,0.366,0.490,0.474,0.583 \%$ で平均
0. 499\% と高い傾向があった(分散比 5. 00, 信頼度 $92 \%$ ).

\section{4) カルシウム}

汁液中のカルシウム濃度は要因による有意な差はみら れず全平均 $0.182 \%$ であった。

\section{5）マグネシウム}

汁液中のマグネシウム濃度は酸素添加の有無により影 響された。即ち, 酸素無添加区で平均 $0.044 \%$ あっあ たのに対し, 酸素添加区では平均 $0.053 \%$ と高い傾向 があった(分散比 2.57 , 信頼度 $83 \%$ ).

汁液分析法 ${ }^{17)}$ は汁液中の可溶性無機元素の濃度を測定 して栄養診断を行う。リン低濃度区の酸素添加区と, リ ン標準濃度区の汁液中リン濃度が同等の值となった。こ れは,リンに特徵的に見られた現象であった。 
Table 5 Effect of supersaturation of dissolved oxygen on inorganic composition analysis of tomato plants

\begin{tabular}{|c|c|c|c|c|c|c|c|c|c|c|c|c|c|}
\hline \multicolumn{4}{|c|}{ Test items } & \multicolumn{10}{|c|}{ Content (\%) of dry weight } \\
\hline \multirow{2}{*}{$\mathrm{O}_{2}$ gas } & \multirow{2}{*}{$\begin{array}{l}\text { Nitrate } \\
\text { concentration }\end{array}$} & \multirow{2}{*}{$\begin{array}{l}\text { Phosphate } \\
\text { concentration }\end{array}$} & \multirow{2}{*}{ Heater- } & \multicolumn{5}{|c|}{ Fruit } & \multicolumn{5}{|c|}{ Stem and leaves } \\
\hline & & & & $\mathrm{N}$ & $P$ & $\mathrm{~K}$ & $\mathrm{Ca}$ & $\mathrm{Mg}$ & $\mathrm{N}$ & $\mathrm{P}$ & $\mathrm{K}$ & $\mathrm{Ca}$ & $\mathrm{Mg}$ \\
\hline \multirow{14}{*}{ supplemented } & \multirow{6}{*}{ standard } & \multirow{2}{*}{ standard } & $\mathrm{E}$ & 2.58 & 0.53 & 2.52 & 0.10 & 0.112 & 2.55 & 0.14 & 4.09 & 3.80 & 0.65 \\
\hline & & & $\mathrm{NE}$ & 2.28 & 0.50 & 2.62 & 0.09 & 0.115 & 2.02 & 0.14 & 4.16 & 3.99 & 0.79 \\
\hline & & avg. & & 2.43 & 0.51 & 2.57 & 0.09 & 0.113 & 2.28 & 0.14 & 4.12 & 3.90 & 0.72 \\
\hline & & \multirow{2}{*}{ low } & $\mathrm{E}$ & 2.30 & 0.46 & 2.39 & 0.08 & 0.102 & 2.18 & 0.14 & 4.08 & 3.40 & 0.69 \\
\hline & & & $\mathrm{NE}$ & 2.50 & 0.44 & 2.35 & 0.10 & 0.109 & 2.53 & 0.14 & 3.95 & 3.38 & 0.68 \\
\hline & & \multicolumn{2}{|l|}{ avg. } & 2.40 & 0.45 & 2.37 & 0.09 & 0.105 & 2.35 & 0.14 & 4.02 & 3.39 & 0.68 \\
\hline & avg. & & & 2.42 & 0.48 & 2.47 & 0.09 & 0.109 & 2.32 & 0.14 & 4.07 & 3.64 & 0.70 \\
\hline & \multirow{6}{*}{ low } & \multirow{2}{*}{ standard } & $\mathrm{E}$ & 2.26 & 0.46 & 2.37 & 0.11 & 0.107 & 2.10 & 0.14 & 3.37 & 4.33 & 0.73 \\
\hline & & & $\mathrm{NE}$ & 2.06 & 0.43 & 2.18 & 0.10 & 0.102 & 1.99 & 0.12 & 3. 41 & 3.57 & 0.61 \\
\hline & & avg. & & 2.16 & 0.45 & 2.28 & 0.10 & 0.104 & 2.05 & 0.13 & 3.39 & 3.95 & 0.67 \\
\hline & & \multirow{2}{*}{ low } & $\mathrm{E}$ & 2.63 & 0.49 & 2.50 & 0.16 & 0.115 & 2.24 & 0.11 & 4.17 & 4.28 & 0.77 \\
\hline & & & $\mathrm{NE}$ & 1.91 & 0.40 & 2.35 & 0.10 & 0.101 & 1.61 & 0.09 & 3.71 & 3. 45 & 0.70 \\
\hline & & \multicolumn{2}{|l|}{ avg. } & 2.27 & 0.44 & 2.42 & 0.13 & 0.108 & 1.92 & 0.10 & 3.94 & 3.86 & 0.74 \\
\hline & \multirow[t]{2}{*}{ avg. } & & & 2.21 & 0.45 & 2.35 & 0.11 & 0.106 & 1.98 & 0.11 & 3.66 & 3.91 & 0.70 \\
\hline avg. & & & & 2.31 & 0.46 & 2.41 & 0.10 & 0.108 & 2.15 & 0.13 & 3.87 & 3.78 & 0.70 \\
\hline \multirow{14}{*}{ not supplemented } & \multirow{6}{*}{ standard } & \multirow{2}{*}{ standard } & $\mathrm{E}$ & 2.36 & 0.50 & 2.60 & 0.07 & 0.110 & 2.20 & 0.06 & 3.80 & 3.80 & 0.68 \\
\hline & & & $\mathrm{NE}$ & 2.26 & 0.44 & 2. 42 & 0.11 & 0.107 & 2. 48 & 0.17 & 4. 34 & 3. 92 & 0.70 \\
\hline & & avg. & & 2.31 & 0.47 & 2.51 & 0.09 & 0.108 & 2.34 & 0.11 & 4.07 & 3.86 & 0.69 \\
\hline & & \multirow{2}{*}{ low } & $E$ & 2.50 & 0.44 & 2.58 & 0.14 & 0.121 & 1.99 & 0.11 & 4.85 & 4.22 & 0.83 \\
\hline & & & $\mathrm{NE}$ & 2.18 & 0.41 & 2. 45 & 0.08 & 0.108 & 2.08 & 0.05 & 3.34 & 3.23 & 0.46 \\
\hline & & \multicolumn{2}{|l|}{ avg. } & 2.34 & 0.42 & 2.51 & 0.11 & 0.114 & 2.03 & 0.08 & 4.09 & 3.72 & 0.64 \\
\hline & \multirow[t]{2}{*}{ avg. } & & & 2.33 & 0.45 & 2.51 & 0.10 & 0.111 & 2.19 & 0.10 & 4.08 & 3.79 & 0.67 \\
\hline & & standard & $E$ & 2.57 & 0.46 & 2.49 & 0.13 & 0.122 & 1.97 & 0.13 & 3.96 & 3.62 & 0.64 \\
\hline & \multirow{5}{*}{ low } & standard & $\mathrm{NE}$ & 2.33 & 0.40 & 2.56 & 0.08 & 0.102 & 2.28 & 0.16 & 4. 11 & 3.19 & 0.79 \\
\hline & & avg. & & 2.45 & 0.43 & 2.53 & 0.10 & 0.112 & 2.12 & 0.14 & 4.03 & 3.41 & 0.71 \\
\hline & & low & $\mathrm{E}$ & 2.32 & 0.44 & 2.49 & 0.20 & 0.116 & 1.98 & 0.07 & 3.62 & 2.15 & 0.55 \\
\hline & & $10 \mathrm{~W}$ & $\mathrm{NE}$ & 2. 16 & 0.40 & 2.33 & 0.10 & 0.105 & 1.97 & 0.05 & 3.27 & 3.97 & 0.69 \\
\hline & & avg. & & 2.24 & 0.42 & 2.41 & 0.15 & 0.111 & 1.97 & 0.06 & 3.44 & 3.06 & 0.62 \\
\hline & avg. & & & 2.35 & 0.43 & 2.47 & 0.13 & 0.111 & 2.05 & 0.10 & 3.74 & 3.24 & 0.67 \\
\hline avg. & & & & 2.34 & 0.44 & 2.49 & 0.12 & 0.111 & 2.12 & 0.10 & 3.91 & 3.51 & 0.67 \\
\hline
\end{tabular}

$\mathrm{E}$; equipped, $\mathrm{NE}$; not equipped

\section{4. 果実および茎葉部の無機成分含有率}

果実および茥葉部の無機成分含有率結果をTable 5 に示した.

\section{1）全窒素}

果実の窒素含有率は加温装置使用の有無により影響さ れた. 即ち, 加温装置未使用区は $2.28,2.50,2.06$, $1.91,2.26,2.18,2.33,2.16 \%$ で平均 $2.21 \%$ であった のに対し，加温装置使用区では 2. 58, 2.30，2.26，2.63， $2.36,2.50,2.57,2.32 \%$ で平均 $2.44 \%$ と高い傾向が あった（分散比 5.47 , 信頼度 $93 \%$ ).

茎葉の窒素含有率は窒素施肥濃度により影響された。 即ち, 窒素低濃度区は $1.98,2.05 \%$ と平均 $2.01 \%$ であ ったのに対し，窒素標準濃度区では $2.32,2.19 \%$ で平 均 $2.25 \%$ と高い傾向があった(分散比 3.30 , 信頼度 $87 \%$ ).

\section{2) リ ン}

果実のリン含有率は酸素添加の有無に影響された。即 ち, 酸素無添加区で平均 $0.44 \%$ であったのに対し, 酸 素添加区では平均 $0.46 \%$ と高かった（分散比 9.08 , 信頼 度 $97 \%$ ）。また，窒素施肥濃度にも影響された。即ち， 窒素低濃度区は $0.45,0.43 \%$ で平均 $0.44 \%$ であったの に対し，窒素標準濃度区では $0.48,0.45 \%$ で平均 $0.46 \%$ と高かった(分散比 10.47 ，信頼度 $97 \%$ )。さらに リン施肥濃度にも影響され，リン低濃度区は 0.45 , $0.44,0.42,0.42 \%$ で平均 $0.43 \%$ であったのに対し， リン標準濃度区では $0.51,0.45,0.47,0.43 \%$ で平均 $0.47 \%$ と高かった(分散比 12.32 , 信頼度 $98 \%$ )。 また, 加温装置使用の有無により影響された。即ち, 加温装置 未使用区は $0.50,0.44,0.43,0.40,0.44,0.41,0.40$, $0.40 \%$ で平均 $0.43 \%$ であったのに対し，加温装置使用 
有区では $0.53,0.46,0.46,0.49,0.50,0.44,0.46,0$. $44 \%$ で平均 $0.47 \%$ と高かった(分散比 25.63 , 信頼度 $99 \%)$.

茎葉のリン含有率は酸素添加の有無にも影響された。 即ち, 酸素無添加区で平均 $0.10 \%$ であったのに対し, 酸素添加区では平均 $0.13 \%$ と高い傾向があった(分散 比 3.69 , 信頼度 $88 \%)$ 。また，リン施肥濃度により影響 された. 即ち,リン低濃度区は $0.14,0.10,0.08$, $0.06 \%$ で平均 $0.10 \%$ であったのに対し，リン標準濃度 区では $0.14,0.13,0.11,0.14 \%$ で平均 $0.13 \%$ と高い 傾向があった (分散比 6.17 , 信頼度 $94 \%$ ).

\section{3) カリウム}

果実のカリウム含有率は要因による有意な差はみられ ず全平均 $2.45 \%$ であった.

茎葉のカリウム含有率は窒素施肥濃度により影響され た. 即ち, 窒素低濃度区は 3.66, 3.74\% で平均 3.70\% であったのに対し, 窒素標準濃度区では 4. 07, 4. 08\% で平均 $4.08 \%$ と高い傾向があった (分散比 2.78 , 信頼度 $84 \%)$.

\section{4） カルシウム}

果実のカルシウム含有率は窒素施肥濃度に影響された。 即ち, 窒素標準濃度区で $0.09,0.10 \%$ で平均 $0.10 \%$ で あったのに対し, 窒素低濃度区では $0.11,0.13 \%$ で平 均 $0.12 \%$ と高い傾向があった(分散比 5.49 , 信頼度 93\%). リン施肥濃度にも影響された。即ち, リン標準 濃度区は $0.09,0.10,0.09,0.10 \%$ で平均 $0.10 \%$ であ ったのに対し，リン低濃度区では $0.09,0.13,0.11,0$. $15 \%$ で平均 $0.12 \%$ と高い傾向があった(分散比 5.71 , 信頼度 93\%). 加温装置使用の有無により影響された。 即ち, 加温装置未使用区は $0.09,0.10,0.10,0.10$, $0.11,0.08,0.08,0.10 \%$ で平均 $0.10 \%$ であったのに 対し, 加温装置使用区では $0.10,0.08,0.11,0.16$, $0.07,0.14,0.13,0.20 \%$ で平均 $0.12 \%$ と高かった(分 散比 7.90 , 信頼度 $96 \%$ ).

茥葉のカルシウム含有率は要因による有意な差はみら れず全平均 $3.64 \%$ であった。

\section{5）マグネシウム}

果実のマグネシウム含有率は加温装置使用の有無によ り影響された。即ち, 加温装置未使用区は $0.115,0$. $109,0.102,0.101,0.107,0.108,0.102,0.105 \%$ で平 均 $0.106 \%$ であったのに対し, 加温有装置使用区では $0.112,0.102,0.107,0.115,0.110,0.121,0.122,0$. $116 \%$ で平均 $0.113 \%$ と高い傾向があった(分散比 5.77 , 信頼度 $93 \%$ ).

茎葉のマグネシウム含有率は要因による有意な差はみ
られず全平均 $0.68 \%$ であった。

酸素添加による溶存酸素濃度の過飽和状態により, 果 実および茎葉のリンの含有率が増加されたが, 他の無機 元素の含有率には影響はなかった。 また, 培養液の加温 により果実の窒素, リン，カルシウム，マグネシウムの 含有率が増加した。

\section{まとめ}

培養液中溶存酸素濃度を過飽和状態にすることにより 草丈, 茎葉生重, 根重量の増加の傾向があった。また汁 液中, 茎葉, 果実のリン含有率が増加した。しかし, 果 実の収量には影響がなかった。これらのことより, 溶存 酸素濃度の過飽和状態がほうれん草などそ菜類の生育促 進におよぼす影響の検討, 溶存酸素濃度の過飽和状態が リンの吸収に及ほす影響の検討, トマトの果実を摘果す る栽培での溶存酸素濃度の過飽和状態が果実の収量にお よぼす影響の検討が必要であると考えられる。

\section{謝辞}

栽培管理および設備管理に御協力下さいました有限会 社不動の茠部誠氏に御礼申し上げます．また，原子吸光 光度計使用の便宜を計って下さった本学の竹迫鉱先生に 御礼申し上げます。

\section{引用文献}

1）養液栽培研究会編：養液栽培マニュアル 21 , 誠分 堂新光舎, pp. 162-163(1998)

2）社団法人農山漁村文化協会編：野菜園芸大百科 15 共通技術・先端技術, pp. 387-392 (1998)

3）林 圭脘, 房 薇, 岩尾俊男, 藤浦建史, 竹山光 一：養液栽培システムの改善に関する研究(II) 一トマトの生長量と溶存酸素量及び蒸散流量との 関係一, 島根大学農学部研究報告, $27: 33-37$ (1993)

4) Yoshida, S., Kitano, M., and Eguchi, H.: Growth of Lettuce Plants (Lactuca sativa L.) Under Control of Dissolved $\mathrm{O}_{2}$ Concentration in Hydroponics, Biotronics $26: 39-45$ (1997)

5）吉田 敏, 北野雅治, 江口弘美：水耕における溶 存 $\mathrm{O}_{2}$ 濃度制御下のキュウリ植物の生育, 生物環 境調節 $34: 223-229$ (1996)

6）吉田 敏, 北野雅治, 江口弘美: 水耕における溶 存 $\mathrm{O}_{2}$ 濃度制御下のキュウリ植物の吸水, 生物環 境調節 $34: 53-58$ (1996)

7）位田藤久太郎, 小川幸持, 新井和夫：蔬菜の根の 生理に関する研究, 園芸学会雑誌, 26 ：171-177 
(1952)

8）中林和重, 田中剛毅, 平沢公雄 : 養液栽培におけ る気泡水の利用がトマトの地下部および生育に及 ぼす影響, 日本生物環境調節学会 1998 年大会講 演要旨, pp. 452-453(1998)

9）田口玄一：実験計画法 上, 丸善, pp. 143-150 (1988)

10) Carol Reiss : Experiments in Plant Physiology, Experiment 12, pp. 107-110(1994)

11）土壤養分測定法委員会編 : 土壌養分分析法, 養賢 堂, pp. 171-176(1981)

12）土猿養分測定法委員会編：土壌養分分析法, 養賢 堂, pp. 227-229(1981)

13）Walter, L. : 植物生態生理学, シュプリンガー・
フェアラーク東京, pp. 233-240 (1999)

14）社団法人農山漁村文化協会編：野菜園芸大百科 2 トマト, pp. 305-324(1988)

15）重松 武：促成ミニトマトの安定生産技術，今月 の農業農薬・資材・技術，41:55-59(1997)

16）枡田正治，野村眞史：トマトの摘心および果実除 去が根の養分吸収と酸素消費に及ぼす影響, 園芸 学会雑誌, 64 : 73-78(1995)

17）藤原俊六郎, 六本木和夫, 安部清悟: 葉柄搾汁液 による窒素(硝酸) 栄養診断一イチゴ一, 農業技術 大系 土壤施肥編 4 土壤診断 - 生育診断, pp. 288(1995) 